\title{
Divining Domination: Steve Bannon as a Political Mystagogue
}

\author{
Tony Allen Feldmann
}

Right-wing commentators (on tv, radio, newspapers, documentaries, or the internet) are often considered a source of misinformation and radicalization in American politics. Understanding the role of such commentators in the political sphere has taken on new significance since the election of Trump, who regularly takes talking points as well as political advice from prominent figures in right-wing media. The purpose of these political "shock jocks" also extends beyond mere political commentary: They offer their audience a framework for understanding the world. This framework contains certain reified perceptions of society and history. Durkheim and those working in his tradition have long recognized that the reification of social forces forms the basis for religious, magical, and mystical beliefs and practices. Therefore, these hosts offer their audience a form of political mysticism. In this article, I will discuss a Durkheimian perspective of religion and magic, and I will show how it can be productively applied to Steve Bannon's political ideology. I argue that from a Durkheimian perspective, Steve Bannon is a mystagogue, a modern diviner and diviner of the modern, who, to varying degrees, offers his followers a mystical worldview. I also argue that a central part of the dynamic between host and listener is the same as what O'Keefe argued is the core dynamic of magic: the defense of the self against society. This theoretical perspective opens a new way of understanding certain political movements while shedding light on the dangerous phenomena of personalization.

\section{Introduction}

Steve Bannon was the chief executive of Donald Trump's presidential campaign. Before this role, he was the executive chief and cofounder of the right-wing online news outlet Breitbart News. Since 2004 he has also directed and produced several conservative-leaning documentaries (Green 2017a). If you were to watch Steve Bannon's 2016 documentary Torchbearer, then you might come away with the idea that ISIS poses the same threat to today's global order as the Nazis did in the 1940s. The documentary implies that America may need to engage in a similar military endeavor against this rising threat as it did in WWII. Importantly, to Steve Bannon, this coming war is not simply the product of recent historical clashes between Western and Middle East nations. Rather, it is the result of a nefarious group of elites who are the product of the unfolding of natural and immutable cycles of human history. Indeed, to Steve Bannon, the only way civilizations achieve prosperity and freedom is through these cycles of violent renewal, and America is currently on the brink. Such claims by Bannon cannot be understood simply as types of framing or propaganda; they provide a narrative about the source and nature of contemporary social problems, threats to "American" or "Western" institutions, and even evil. Furthermore, Bannon promotes particular reified social forces and regards certain groups as embodiments of those forces. I argue that Bannon acts as a mystagogue to the extent that he advocates these ideas.

Durkheim argued that when certain representations, symbols, or objects are placed at the center of collective life, people tend to misperceive their social role as the product of something other than collective practice. To Durkheim, such misperception sits at the core of religious and magical practices. I use Durkheimian insights into religion and magic to theorize the role and discourse of Steve Bannon. I focus on Bannon's 2010 documentary Generation Zero 
because it depicts central aspects of his political worldview (Greenberg 2017; Green 2017a).

Durkheim's thought can be productively used for critical sociological analysis (Jones, 2001; Smith 2006; Thompson 2016; Gangas 2007; Worrell 2018). Alienation and exploitation are social practices that aren't simply carried out by those with guns and a callous self-interest, though this certainly does happen. "In reality, however, society's hold on the mind owes far less to its physical supremacy than it does to the moral authority with which it is invested. We defer to its rules, not simply because it has the weapons to overcome our resistance, but above all, because it is the object of genuine respect" (Durkheim [1912] 2001:155). People not only regularly view different forms of domination as legitimate, but they often demonize anyone who criticizes such practices. People build up grand narratives celebrating the greatness and necessity of their government to deny certain groups of people their human rights. This fact does not mean that authoritarianism is inevitable. Rather, the point is that social structures and institutions are always alloyed with subjectivity. As Thompson argues, "we need to see social power and domination as a social fact that is embedded in social structures, but that these structures and forms of power are social facts produced by the routinization of consciousness to think along the lines of specific cognitive rule-sets, norms, and value-orientations" (2016: 3-4). In a broad sense, my interest is how certain political narratives relate to social facts and structures. Durkheimian insights into religion and magic can be productively used to this end.

\section{Religion and Reification}

Durkheim's Elementary Forms of Religious Life (EFRL) ([1912] 2001) does not simply provide a theory of religion; it can also be viewed as a roadmap to the sui generis effects of collective human practices. New phenomena occur when people come together and interact, new sentiments, thoughts, and behaviors are created, and they have unique consequences. Durkheim's central notion is the social fact. I define a social fact as any collective way of acting, thinking, and feeling that is external, coercive, and irreducible to the individual (Durkheim 1982: 50-59; Worrell, 2018). Social facts are a product of collective activity and as such only exist to the extent that people engage in them. However, they also exist independent of any one person's participation (Durkheim 1982: 55). This idea of a social fact may seem trivially true and pragmatic (obviously people interact, discuss, share, relate, and so on), but Durkheim was critical of pragmatism (Durkheim 1983) and had a more complicated conception in mind. People do not simply come and go from social facts based on their whim. Social facts are coercive, and not simply because disobeying them can result in violence. They are coercive in part because of the dual nature of human subjectivity.

Durkheim argued that we are homoduplex in that the psychic life of people has two aspects: individual and social. "Strictly individual, these states of consciousness attach us only to ourselves, and we can no more detach them from us than we can detach ourselves from our body. The others, on the contrary, come from society; they translate it in us and attach us to something that goes beyond us. Being collective, they are impersonal; they turn us towards ends that we share in common with other men; it is through them and through them alone that we can commune" (Durkheim 2005: 44). Representations and emotions are just as much a part of any given social fact as is behavior. We represent and justify our collective practices to ourselves. "Collective representations are the product of a vast cooperative effort that extends not only through space but over time; their creation has involved a multitude of different minds associating, mingling, combining their ideas and feelings..." (Durkheim [1912] 2001: 18). How we think and feel about our identities, roles, relationships, etc. is shaped by our collective representations. Thus, society is not simply networks of people interacting, but it is also a conceptual thing, part of all of our consciousnesses (see Worrell, 2018). Durkheim brilliantly articulates this in the Introduction of EFRL: "If at any given moment men did not agree on these essential ideas ... then any agreement between minds, and therefore, all common life would become impossible. So society cannot abandon these categories to the free will of particular individuals without abandoning itself. To live, society needs not only a degree of moral conformity but a minimum of logical conformity as well" (Durkheim [1912] 2001: 19). Thus, society consists of both the interactions we have and the concepts we share. Society is not just the physical consequences we bring on one another but also the statuses and sentiments we together confer on people, places, objects, and practices. I emphasize this point because authority within society is the product of people collectively conferring a certain status onto a person. We obey and defer to someone or a group because we have invested them with moral authority.

An important tendency is that we often get lost to these projective practices and become blind to the properly social basis of authority. Marx makes this point in a footnote in chapter 1 of Capital: "For instance, one man is king 
only because other men stand in the relation of subjects to him. They, on the other hand, imagine that they are subjects because he is king" ([1867] 149) (Smith (1988) was the first to notice the similarity between Marx's analysis of the commodity and Durkheim's analysis of the totem). Marx used the concept of fetishism to describe how people mistakenly attribute autonomous powers to commodities and the capitalist mode of production (Smith 2006). We regularly misperceive the products of collective practices to stem from something other than collective practices. In other words, we reify them.

A Durkheimian perspective on reification differs in an important respect from more traditional ways of viewing reification. Since Lukacs, it has been common to think of reification as the process by which humans don't see or forget the role they play in creating the social world. This viewpoint is taken up by Berger and Luckmann: "Reification implies that man is capable of forgetting his own authorship of the human world, and further, that the dialectic between man, the producer, and his products is lost to consciousness" (Berger and Luckmann 1967: 89). Such forgetting certainly happens, but Durkheim has a more complicated perspective. For Durkheim, people don't just lose sight of the social; they actively confer something new onto people, places, objects, and practices: moral authority. People misperceive the moral authority they have granted to something as stemming from that thing-in-itself. They believe that a thing possesses certain qualities, substances, forces, or spirits that cause them to have reverence for it (anthropologists and sociologists have offered different ways of conceptualizing this side of reification; see Ellen, 1988 and Silva, 2013). Thus, people are not just passively trampled because they don't notice their authorship of social forces; rather they participate in their alienation by misperceiving the moral status they confer onto things as a reflection of those things in-themselves. People often get ensnared in a trap of their own making, and, as Durkheim points out in Suicide (1951), they can even lose their lives to it. Durkheim's analysis of totemism results in him making this point.

Durkheim views religion as a particular social fact which is characterized by a specific set of collective beliefs and practices. "A religion is a unified system of beliefs and practices relative to sacred things, that is to say, things set apart and surrounded by prohibitions-beliefs and practices that unite its adherents in a single moral community called a church" (Durkheim [1912] 2001: 46). Durkheim argued in totemic religions the clan does not worship the totem per se because they also have rites regarding basically any representation of the totem including the totemic animal. So, the clan is concerned with something that is shared by the totem, the totemic animal, and any totemic representation but is not reducible to any one of them in particular. Thus, the totem has a two-fold nature: in the concrete, it is an image of a particular animal, and in the abstract, it is a bearer of a universal substance/quality/force (Durkheim [1912] 2001). The totem is just the "material form in which that immaterial substance is represented ... this energy alone is the true subject of the cult" (Durkheim [1912] 2001: 141). This force is what Durkheim calls the totemic principle or mana, and the clan believes that it is what sustains the life of clan members "as well as all things that are classified under the totem and participate in its nature" (Durkheim [1912] 2001: 152). Belief in mana or the totemic principle is a belief in a substance/quality/force that is shared by the clan, the totem, etc. and accounts for their essential nature, sustains their existence, and is not identical to anyone of them in particular.

The basis for this sense of something internal and external, individual and shared, essential and impersonal, unseen and powerful is society itself. "Religious force is the feeling the collectivity inspires in its members, but projected outside and objectified by the minds that feel it. It becomes objectified by being anchored in an object which then becomes sacred, but any object can play this role... Hence the sacred character that garbs a thing is not implicated in its intrinsic features, it is added to them. The world of the religious is not a particular aspect of empirical nature: it is superimposed" (Durkheim [1912] 2001: 174). The totemic principle is a reified collective representation. The members of the clan misperceive the collective status of the totem as a reflection of some inherent mystical quality or sacredness. Such a misperception is not the result of some deficiency on the part of premodern people; it does not stem from an inability to reason correctly (which has been a common argument among social scientists in the past see Styers 2004). Rather, this misperception comes from the very way in which people experience collective practices and representations. "Collective representations ... presuppose that consciousnesses act on and react to one another; they are the result of these actions and reactions, which are possible only through tangible intermediaries. These tangible intermediaries, then, not only reveal the mental state associated with them, they contribute to creating it" (Durkheim [1912] 2001: 175). The clan represents itself to itself with an emblem, and just as a person is socialized into respecting the norms of the clan, it comes to relate such respect to the different appearances of the emblem (in the totem, totemic animal, or other clan members).

During rituals, ceremonies, or festivals people experience powerful social forces that generate strong amounts of emotional excitation or collective effervescence. Such effervescence is real. It is just purely social. As a purely social 
substance, it only materially manifests in the image of the emblem or the actions of others. "Generally, a collective feeling can become self-conscious only by being anchored in a material object" (Durkheim [1912] 2001: 180). People misperceive the social effects they have on one another to be a reflection of some sacred force or mana that is shared by everyone in the group as well as the group's emblem. "[In EFRL] we set out to show that sacred things are simply collective ideals attached on to material objects" (Durkheim 2005: 42). The idea of the sacred isn't something that each clan member happens to arrive at independently because of the structure of institutions. Rather, the clan collectively and openly believes in sacred forces, and this belief results from the social forces they experience, which they reify and project onto certain people, places, objects, and practices.

Sacred forces are often of either a positive or a negative type. The positive type or pure mana is often viewed as a "benevolent, guardians of the physical and moral order, dispensers of life, health, all the qualities that men value" (Durkheim [1912] 2001: 304). The totemic principle is an instance of pure mana. The negative type or impure mana creates "disorder, cause[s] death and illnesses, and instigate sacrilege" (Durkheim [1912] 2001: 304). Just as the sacred is kept separate from the profane, religious practices also involve keeping pure and impure mana separate. As with the totemic principle, impure mana is the misperception of collectively conferred negative status upon certain people, places, objects, and practices for a reflection of some inherent substance or force.

The dynamics of reification are different in Modern society than that of the clan societies that Durkheim studied. Modern people are subject to powerful, distant, and impersonal market forces. The alienating effects of globalized capitalist accumulation can leave people disoriented as they are unable to readily see why society is constantly transforming. Adorno argued that people rely on reified collective representations to provide a "pseudoorientation" (1950: 622). He furthered this line of theoretical analysis with his concept of 'personalization,' which is the "tendency to explain social phenomena that are objectively motivated as the actions of the good or bad persons..." (1950: 663), for example, imagining that an upturn in economic growth is due to the brilliance of a political leader. As Smith argues, "authority fetishism is a response to commodity fetishism" where modern people have a "tendency to explain impersonal social facts as the result of acts by charismatic figures visualized either as enemies or as authorities" (2006: 102-103).

From a Durkheimian perspective, it is not surprising that we find political behavior that is analogous to religion and magic because both sets of human practices are centered around emotionally charged representations and identities. Scholars have long noticed such parallels, and some have proposed concepts like 'political religions' to refer to them (Gentile 2005). At times in modern politics, people can attribute mana-like qualities to certain figures or groups. The supremacy of a group deemed to have positive qualities or pure mana and the denial of human rights to the group deemed in possession of negative qualities or impure mana is all but assured when they emerge in modern politics because the pure cannot comingle with the impure without devastating consequences. I will argue that personalization is a major part of Steve Bannon's politics and that he is, therefore, acting as a mystagogue. I will need to discuss magic and its relation to religion before I explore Steve Bannon's political worldview.

\section{Magic}

Religion and magic cannot always be disentangled because they deal in the same reified social forces. Still, these two social facts tend to have certain roles, beliefs, and practices that are unique to each. I will be focusing on the magician, the laws of magic, and the role of magic within society as analyzed by Mauss as well as O'Keefe. I have chosen these two theorists because they are the two foremost Durkheimian theorists of magic.

Magic refers to the manipulation of some substance/quality/force or mana of people, places, objects, or spirits through specific rites causing automatic efficacy at a distance. Like religion, magic shares the belief in mana. "Mana is power, par excellence, the genuine effectiveness of things which corroborates their practical actions without annihilating them" (Mauss 2001: 137). Unlike religion magic does not revere that which bears mana; instead it manipulates its mana to achieve private ends. Though magic is certainly a social practice, it is not a communal activity. As Durkheim says, "a church of magic does not exist" (Durkheim 2001: 43). Magic does not bind a community together. Rather, magic is carried out between a magician and his or her clientele. A magician is simply anyone who deals in magic (Mauss 2001: 31), and magicians offer their abilities to conduct magic to private persons. "The magician is someone who, through his gifts, his experience or through revelation, understands nature and natures" (Mauss 2001: 94). Magicians have special knowledge and capacities which allow them to tap into the mana of things. 
Either they have special knowledge of spells, incantations, ceremonies, potions, ect., or they have exceptional mana which allows them to carry out magic or both. Magicians may develop a following, and Weber classified such figures as mystagogues (Weber 1978).

Mauss pointed out that magic operates through three laws: similarity, contiguity, and opposition. The first law, similarity, has two forms: 'like produces like' and 'like acts on like,' for example, using an 'evil eye' to inflict harm on its recipients. The law of contiguity can be stated as 'the part is in the whole and the whole is in the part,' for example when a psychic needs a piece of a deceased person's property in order to channel his or her ghost. The law of opposition can be formulated as 'like acts on like to produce the opposite.' Mauss gives the example of pouring water on the ground to cause rain and end a drought. The laws of magic are not the source of magical efficacy; they are simply the way in which magical power acts. "Sympathy is the route along which magical powers pass: it does not provide magical power itself" (Mauss 2001: 125). Magical power is based on the mana of things, and in order to manipulate it classification is needed. As the laws of magic illustrate, magic is always dealing in similarities and oppositions, and so the basis for magical practice is in classifying people, places, objects, and practices into groups. "Magic becomes possible only because we are dealing with classified species. Species and classification are collective phenomena." (Mauss 2001: 97). Magical representations will significantly depend on the cultural context because what counts as similar or opposite will depend on an already existing classifying schema.

In an almost criminally neglected work, O'Keefe (1983) provides a stunning synthesis of sociological, psychological, philosophical, and theoretical literature on magic. O'Keefe lays out not only a fascinating theory of magic but also a socio-historical argument of its relation to religion, science, and individualism. O'Keefe argues that magic is a defense of the self against the social by building off of the insights, particularly of Durkheim, Weber, and Freud. "If religion is the projection of the overwhelming power of the group, and if magic derives from religion, but sets itself upon a somewhat independent basis to help individuals, and is, at the same time, frequently reported to be hostile towards religion...then is not the answer apparent? Magic is the expropriation of religious collective representations for individual or subgroup purposes - to enable the individual ego to resist psychic extinction or the subgroup to resist cognitive collapse" (O’Keefe 1983: 14). O’Keefe's Freudian model causes him to emphasize the ego-defense aspect of magic wherein the individual uses collective representations to resist being overwhelmed by the collective consciousness. My interest, however, is in the first aspect of O'Keefe's insightful conception of magic. From a Durkheimian perspective, the notion of mana is eminently social; it is based on reified collective representations. Magic's reliance on mana to achieve its goals demonstrates its collective roots. The magician is, therefore, someone who through their special knowledge uses and reworks reified collective representations for his or her clientele. Horoscopes are perhaps an ideal-typical model of magic. The astrologer uses their special knowledge into the mystical relationship between constellations and date of birth to offer readers insights into themselves and their futures.

O'Keefe argues that the constant expropriation of religious representations, both attacks and renews religion. Sometimes it may lead to the establishment of a new religion. Magicians are in this way cultural entrepreneurs who facilitate a change in people's relations to the sacred and therefore society itself. "Magic is the art of changing" (Mauss 2001: 76). It is in this light that I will argue we need to view certain political commentators.

\section{| Political Mystagogue}

Politics is not just the battle for power-it also entails struggles over collective representations and collective identity. Certainly, there are soulless Macbeths who are willing to engage in various Machiavellian schemes to attain power. Still, power is a conferred status and all aspiring political leaders must contend with existing collective sentiments if they ever hope to get that status conferred on them. Every revolution is a demonstration that even when someone seemingly has an iron grip on a population, their hold can give out suddenly if a critical mass of people resists. Political commentary and propaganda entail the struggle over the meaning of certain events, policies, statements, etc. It also entails the struggle for the collective sentiment. Political commentators are entrepreneurs of collective sentiment; innovating new arguments, rationalizations, and narratives. ${ }^{1}$

Steve Bannon states that Western society is in the middle of a crisis brought about by decadent liberal elites, and he is not alone. Several right-wing political commentators have promoted similar populist narratives. Glenn Beck, CEO and founder of a right-wing TV and radio network and former Fox News host, in his book Liars: How 
Progressives Exploit Our Fears for Power and Control (2016) claims that liberal elites use scare tactics to push big government on the unsuspecting public to gain power and, ultimately, overthrow capitalism and the republic. Other conservative commentators like Tucker Carlson (2018), a Fox News host, and Ben Shapiro (2019), who is an author, former editor-at-large for Breitbart News, and hosts the right-wing podcast The Ben Shapiro Show, promote similar ideas of how liberal elites have caused America to lose its way. In 2019 Rush Limbaugh, a right-wing radio host, claimed that liberal elites refuse to stop "this mass movement of illegal immigrants from Central America" because those immigrants will help them overthrow the American republic. To Rush Limbaugh, this behavior on the part of elites is rooted in their deep animosity towards average American citizens and the foundations of the American republic, i.e., the Constitution, capitalism, and Christianity. Jeanine Pirro (2018), a Fox News host, argues that there exists a "Deep State" of unelected government employees who mooch off taxpayers and who have conspired to undermine Donald Trump's presidency. Steve Bannon, however, takes these ideas further than his fellow commentators.

Bannon has a seemingly contradictory political worldview. He self-identifies as a conservative and an economic nationalist (Nelson 2016; Mead 2010). On the surface, Bannon seems like a standard American conservative; he endorses Christian values, supports capitalism, and promotes limited government. However, a more esoteric view of history rests underneath such staples of contemporary American conservatism. The journalist Joshua Green, who personally knows Bannon, articulates some of these contradictions in his book about Bannon's time working for Donald Trump's campaign (2017a). According to Green, Bannon has been significantly influenced by a number of anti-Modernist thinkers like metaphysician and occultist Rene Guenon (whose work Bannon has described as "a life-changing discovery"), the Italian fascist theorists and occultist Julius Evola (who was influenced by Guenon), and the Russian fascist theorists and occultist Alexander Dugin (who was influenced by Guenon and Evola; Green 2017a: 206). ${ }^{2}$ Bannon takes three key ideas from Guenon: (1) time is cyclical, (2) the West is in the middle of a six-millennialong period of spiritual decline wherein tradition is slowly being forgotten, and (3) the best way ignite a spiritual renewal is through converting a group of elites to spread the message (Green 2017b). Green (2017a) writes about how Bannon is drawn to these writers for two main reasons: they emphasize the importance of tradition and the decadence of modern globalization. So, Bannon endorses modern institutions like the nation-state, a representative republic, and industrialized capitalism, but he also promotes a return to Medieval Christian spiritualism, which some have pointed out never really existed in the way Bannon imagines (Hawk 2019). He bemoans the effects of globalization but supports the economic system driving it.

These contradictions reappear in the principles and policies he promotes. Green claims that Bannon endorses the Catholic concept of subsidiarity, which means that political issues ought to be handled at "the lowest, least centralized authority that can responsibly handle them..." (2017a: 206). Bannon also endorses a strong military, state interference in international trade, and strict immigration controls. Green quotes Bannon saying, "You have to control three things," he explained, "borders, currency, and military and national identity" (2017a: 207). Bannon states that free trade and mass migration are causing "Western Christendom" to lose its "sovereignty" to nonWestern and non-Christian nations, particularly China (BBC 2018). He argues that a liberal globalist elite has pushed mass migration and free trade to suppress wages and enrich themselves, and this accounts for the deindustrialization of America. He states that reversing these policies will reinvigorate America and provide a bulwark for Christian traditionalism. He argues that the post-WWII international order has failed and that nationalism will continue to be ascendant as more people across the West rise to assert their nationalist interests. He envisions a complete reordering of the global economy such that the West is no longer in a "tributary" relationship with China (Ferguson 2018). To Bannon, the biggest obstacle for this transformation is a class of globalist elites.

Bannon believes the elite reached a zenith of corruption and betrayal of Western Christendom after the Great Recession when they bailed themselves out and abandoned the average citizen. Bannon doesn't portray this elite as simply money-grubbing. In his documentary Generation Zero (2010) ${ }^{3}$ Bannon offers an explanation of the Great Recession and he lays out how more nefarious forces are at play than callous self-interest. ${ }^{4}$ Bannon features several representatives from right-wing think tanks and conservative politicians to weave together an overall story. He also uses a rather unorthodox theory of American history based on the pseudoscience (Lind, 1997) of William Strauss and Neil Howe's The Fourth Turning: An American Prophecy (1997). Bannon lays out the argument that American history goes through inevitable and necessary cycles. There are four cycles, each lasts about a generation or twenty years, and a full set of cycles takes about eighty to one hundred years. They move from a period of prosperity and stability to ever-increasing instability and decadence until a crisis point hits and the national system is overthrown, renewed, or remade. This cyclical palingenesis is the only way prosperity is created. There are "only a limited number 
of social moods, which tend to recur in a fixed order" (Howe 2017). America entered this crisis cycle with the onset of the Great Recession. The economic crisis was brought about because the Baby Boomers, who now control our major institutions, have filtered down their selfish, loose, and materialistic values. He argues that culture changes because elites promote new values through government, schools, and media.

The Baby Boomers developed these irresponsible values in the 1960s, and the Great Recession is portrayed as the culmination of the spread of those values. He also argues that the Great Recession was not caused by a lack of regulation. Rather, it was due to the fusion of big government and big business. Starting in the 1990s, according to the documentary, the Democratic Party became convinced that global finance was the most important issue and started subsidizing Wallstreet. International financiers are soaking up more and more of the profit from risky investments while the American middle-class has to pay for their losses. A major way in which the Democratic Party has been able to fuse big government and big business is through guilting white Americans on issues of race. Democrats loosened lending regulations under the guise of trying to help out black Americans who were claiming they had experienced housing discrimination (For a critique of this line of argument see King 2016). Bannon argues that many of these claims are probably lies because the political activist Saul Alinsky advocated lying in order to "get what you want." Thus, the Great Recession is ultimately the fault of the immorality of an elite class of politicians and businessmen, and it is implied that the elite's ultimate goal is to overthrow capitalism. American institutions will go through a crisis that will purify them and lead to a new age of prosperity. As Howe states, "Forests need periodic fires; rivers need periodic floods. Societies, too. That's the price we must pay for a new golden age" (Howe 2017).

Strauss and Howe's theory relies on the reification of collective sentiments. They posit that there are only four collective "moods" or archetypes. Each generation is possessed by an archetype which determines how people of that generation behave politically, culturally, and economically. The archetype of one generation causes changes in institutions and child-rearing practices, which causes the development of the next generation's collective archetype. History is driven by the replacement of one generation after another because a new archetype becomes dominant. Strauss and Howe's theory is based on reification because the archetypes are not seen as a product of the collective activity, rather they determine collective activity. As historian David Greenberg (2017) points out, "the study of human decision-making in the past_or even the present-becomes all but irrelevant" because of the theory's determinism. ${ }^{5}$ Bannon uses their theory in his documentary to rework other collective representations for his largely right-leaning audience. The manner in which he does this allows him to provide an explanation of the Great Recession while shielding conservative values like Christianity, capitalism, and the structure of the U.S. government from criticism. Potentially challenging ideas are foreclosed, and his audience's political identities are affirmed. Bannon is, therefore, acting as a mystagogue by using his special knowledge of reified collective representations to defend a subgroup's social identity against threatening aspects of the social world. There are three central methods Bannon uses to achieve this outcome.

First, Bannon uses Strauss and Howe's theory to advance a specific right-wing conception of what it means to be American. "Judeo-Christian" values, "the work ethic, entrepreneurship, decentralization, local government, [and] volunteerism" are portrayed as the crucial aspects of those archetypes that have established America's leadership on the international stage. The documentary argues that the story about the New Deal, helping to end the Great Depression is wrong. It is claimed that the "little" guys who humbly worked hard and took risks opening new business were the ones who ended the crisis. All recoveries are brought about in the private sector by "the man who pays, the man who prays," according to the documentary. Contemporary right-wing values are reframed as the true source of prosperity and stability. Thus, any person or politician who does not share these values is, at a minimum, betraying what it means to be American.

Second, the documentary personalizes the movements and policies opposed by the right-wing, treating them as if they come from an immoral group of people. In the documentary, the elite have a two-fold nature: in the concrete, they are certain politicians and business leaders, and in the abstract, they are bearers of an immutable negative historical force or impure mana. Bannon's use of vague references to the social and political changes since the 1960s and 1970s reframes the efforts to combat discrimination (particularly against African Americans) as a reflection of moral decline brought about by spoiled selfish Baby Boomers. Policies aimed at helping African Americans are reframed as cynical political ploys that ultimately causes more harm than good to the black community. He reframes government regulation and public programs as a nefarious fusion of big government and big business and a reflection of creeping "secular socialist European-style government." Social security and Medicare are reframed as unfathomably expensive government programs that have put the U.S. government in almost $\$ 100$ trillion in debt and may cause hyperinflation similar to what Germany experienced during the 1920s (for a critique of the numbers Bannon uses to support this 
idea see Kessler 2017). The Affordable Care Act is reframed as the government increasing its control over the daily lives of citizens in an Orwellian fashion. All of these policies are a result of a decadent elite and they are leading to a crisis moment analogous to WWII, the French Revolution, or the Russian Revolution.

Third, Bannon lays out a "Manichean vision" of what is to take place after the Great Recession (Smith 2006). On the one side, there is the decadent, globalist elite who are in control of the government, big business, and big finance and who are undermining American prosperity with excessive federal programs and Wallstreet bailouts. As embodiments of a decadent historical force, they are betraying what it means to be American. On the other side, there are humble workers, diligent entrepreneurs, and faithful Christians who want what is best for their country. Presumably, they are the only group who can stand up and vanquish the corrupt elite.

Bannon's emphasis on the producers versus the unproductive elite, his personalization of historical dynamics he opposes in the form a decadent ruling class, and his apocalyptic tone of American's future have all been standard elements in right-wing populist discourses (Berlet and Lyon's 2000). ${ }^{6}$ In Generation Zero (2010) Bannon goes beyond framing a current event in a politically convenient light. Rather, he portrays it as the beginning of a crisis period that is part of grand immutable historical forces wherein the very existence of the nation is at stake. He uses this reified view to rework collective representations of the 1960s, the Clinton administration, the Democratic

Party, and racial discrimination to explain the Great Recession in a manner that affirms the social identities of conservatives, Republicans, and Tea Party supporters. Bannon is, therefore, acting as a mystagogue. Bannon's efforts to create a right-wing populist movement across Europe and North American to remove the globalist elite and usher the spiritual renewal of Medieval Christianity can be viewed as a piacular ritual. Durkheim explains that such rituals are done "to deflect an evil or expiate a misdeed by extraordinary ritual acts" (Durkheim 2001: 301). Mobilizing a pan-Western, anti-globalist movement to reverse the economic dynamics since the 1980s to expiate a global elite would certainly be extraordinary. Bannon's only hope is that his political mysticism resonates strongly enough with existing collective sentiments.

\section{Conclusion}

Steve Bannon is just one of many political commentators that deals in magical forces. I have focused on him in this essay because he is a mystagogue who has risen to the point of power and influence that most people, yet alone mystagogues, ever reach. Bannon's right-wing populist discourse uses what Adorno saw to be one of the central techniques of reactionary agitation: "the transformation of the feeling of one's own impotence into a feeling of strength" (2000: 42). The alienating effects of capitalism are such that people are pushed around by impersonal, external, powerful forces that they cannot directly see. The immanent dynamics driving capitalism to spread across the globe appear in the form of factories closing, unions disappearing, the rise of retail chains, increases in prices at gas stations and grocery stores, and sometimes, like in 2008, politicians telling them their tax dollars must be used to bail out rich financiers. Commentators like Bannon allow people to feel like they can steal back some power from these seemingly autonomous forces. He does this by personalizing these social forces in the guise of a nefarious elite that needs to be defeated. This technique allows him to account for the failures of the U.S. government and capitalism while shielding them from criticism. He forecloses opportunities for immanent critique by mystifying the structural dynamics behind income inequality, wage stagnation, deindustrialization, the Great Recession, and political corruption (Brenner 2006; Gilens 2014; Kliman 2011; Panitch and Gindin 2012; Piketty 2014; Varoufakis 2011). His Manichean narrative affirms the social identities of conservatives, Republicans, and Tea Party supports by placing the blame largely on the shoulders of liberals, progressives, and Democrats. It also forecloses critical reflection on the part of his viewers, blocking them from noticing that the politicians they support pass policies that ultimately harm them (Hochschild 2016; Metzl 2019). Instead, Bannon allows them to view themselves as heroes in a grand Manichean struggle. It is in this way that reified collective representations and the mystagogues who peddle them contribute to perpetuating modern forms of domination. 


\section{Endnotes}

1. In The Brink, a documentary focused on Bannon's political activity after leaving the White House, Bannon specifically compares the spread of political ideas to the spread of financial ideas across global markets

2. Evola's and Dugin's writings contain some of the most extremist sexist and racist language, which Bannon regularly disavows.

3. It is one of three of Bannon's documentaries that takes a more historical perspective, and it contains central tenants of Bannon's political ideology. See Freelander (2017) for a good summary of all three documentaries.
4. Bannon directed this documentary for the production company Citizens United from the infamous Citizens United vs FEC.

5. Greenberg (2017) also notes that news of Bannon's praise of The Fourth Turning has caused the book to go to number 1 in the "divination" category on Amazon. com

6. His techniques are similar to the "tingling backbone" and "last hour" devices Adorno discusses in his analysis of Martin Luther Thomas radio program

\section{References}

Adorno, Theodor. 1950. "Part 4: Qualitative Studies of Ideology." Pp. 605-783 in The Authoritarian Personality, Adorno et al. New York: Harper and Brothers.

Adorno, Theodor. 2000. The Psychological Technique of Martin Luther Thomas' Radio Addresses. United States of America: Stanford University Press.

Bannon, Steve. 2010. "Generation Zero." Citizens United Productions, United States of America.

BBC, 2018. "Full Interview: Trump's former chief strategist Steve Bannon-BBC News.” Retrieved from https://www.youtube. com $/$ watch?v $=$ mty3c_CARO0

Beck, Glenn. 2016. Liars: How Progressives Exploit Our Fears for Power and Control. New York, NY: Threshold Editions.

Berger, Peter and Thomas Luckmann. 1967. The Social Construction of Reality: A Treatise in the Sociology of Knowledge. United States of America: Anchor Books.

Berlet, Chip and Matthew Lyons. 2000. Right-Wing Populism in America: Too Close for Comfort. New York, NY: The Guilford Press.

Brenner, Robert. 2006. Economics of Global Turbulence. London: Verso Books.

Carlson, Tucker. 2018. Ship of Fools: How a Selfish Ruling Class is Bringing America to the Brink of Revolution. New York, NY: Free Press.

Durkheim, Emile. 1951. Suicide: A Study in Sociology. New York, NY: The Free Press.

Durkheim, Emile. 1982. The Rules of Sociological Method. Edited by Steven Lukes and translated by W.D. Halls. New York: The Free Press.
Durkheim, Emile. 1983. Pragmatism and Sociology. Translated by J. C. Whitehouse, edited by J. Allcock. Cambridge: Cambridge University Press.

Durkheim, Emile. [1912] 2001. Elementary Forms of Religious Life. New York: Oxford University Press.

Durkheim, Emile. 2005. “The Dualism of Human Nature and its Social Conditions." Durkheimian Studies / Études Durkheimiennes, 11, 35-45.

Ellen, Roy. 1988. “Fetishism.” Man (N.S.), 23(2): 213-235

Freelander, Adam. 2017. “The Films of Steve Bannon.” Quartz. Retrieved from https://www.youtube.com/watch?v=ulgOc

Ferguson, Sarah. 2018. "Steve Bannon on how the Strategy that elected Trump is going Global.” ABC News. Retrieved from https://www.youtube.com/watch?v=q8BGvG3pPfo

Gangas, Spiros. 2007. "Social Ethics and Logic: Rethinking Durkheim through Hegel.” Journal of Classical Sociology, $7: 315$

Gentile, Emilio. [2001] 2006. Politics as Religion. Princeton, NJ: Princeton University Press.

Gilens, Martin. 2014. Affluence and Influence: Economic Inequality and Political Power in America. Princeton, NJ: Princeton University Press.

Green, Joshua. 2017a. Devil's Bargain: Steve Bannon, Donald Trump, and the Storming of a Presidency. New York, NY: Penguin Press.

Green, Joshua. 2017b. "Inside the Secret, Strange Origins of Steve Bannon's Nationalist Fantasia." Vanity Fair. Retrieved from https://www.vanityfair.com/news/2017/07/ the-strange-origins-of-steve-bannons-nationalist-fantasia 
Greenberg, David. 2017. "The Crackpot Theories of Steven Bannon's Favorite Authors.” Politico Magazine. Retrieved from https://www.politico.com/magazine/story/2017/04/20/ stephen-bannon-fourth-turning-generation-theory- 215053

Hawk, Brandon. 2019. "Why Far-Right Nationalists like Steve Bannon have Embraced a Russian Ideologue." The Washington Post. Retrieved from https://www.washingtonpost.com/ outlook/2019/04/16/why-far-right-nationalists-like-stevebannon-have-embraced-russian-ideologue/?utm_term $=.11 \mathrm{~b} 7 \mathrm{~d}$ c19b32e

Hochschild, A.R., 2018. Strangers in their own land: Anger and mourning on the American right. New York: The New Press.

Howe, Neil. 2017. "Where did Steve Bannon get His Worldview? From my Book." The Washington Post. Retrieved from https://www.washingtonpost.com/entertainment/books/where-did-steve-bannon-get-his-worldviewfrom-my-book/2017/02/24/16937f38-f84a-11e6-9845576c69081518_story.html?utm_term $=.11 \mathrm{~b} 7 \mathrm{c} 57 \mathrm{~d} 3577$

Jones, Susan. 2001. Durkheim Reconsidered. Malden, MA: Polity Press.

Kessler, Glenn. 2017. "Is the 'Real Number' for the National Debt $\$ 70$ Trillion?” The Washington Post. Retrieved from https:// www.washingtonpost.com/news/fact-checker/wp/2017/ is-the-real-number-for-the-national-debt-70-trillion/?noredirect $=$ on\&utm_term $=.1 \mathrm{e} 007 \mathrm{e} 038313$

King, Mervyn. 2016. The End of Alchemy: Money, Banking, and the Future of the Global Economy. New York, NY: W. W. Norton \& Company.

Klayman, Alison. 2019. “The Brink." AliKlay Productions, United States of America: Magnolia Pictures.

Kliman, A., 2011. The Failure of Capitalist Production: Underlying Causes of the Great Recession. Pluto Press.

Limbaugh, Rush. 2019. "An Explanation of American Exceptionalism for Vladimir Putin and Barack Obama." Retrieved from https://www.rushlimbaugh.com/ daily/2013/09/12/an_explanation_of_american_exceptionalism_for_vladimir_putin_and_barack_obama/

Lind, Michael. 1997. "Generation Gaps.” The New York Times. Retrieved from https://archive.nytimes.com/www.nytimes. com/books/97/01/26/reviews/970126.26lindlt.html?_r=1

Marx, Karl. [1867] 1976 1990. Capital: A Critique of Political Economy, vol. 1. New York, NY: Penguin Group.

Mauss, Marcel. [1902] 2001. A General Theory of Magic. New York, NY: Routledge.

Mead, Rebecca. 2010. "Rage Machine: Andrew Breitbart's Empire of Bluster.” The New Yorker. Retrieved from https://www. newyorker.com/magazine/2010/05/24/rage-machine

Metzl, Jonathan. 2019. Dying of Whiteness: How the Politics of Racial Resentment is Killing America's Heartland. New York, NY: Basic Books.
Nelson, Louis. 2016. “Steve Bannon Hails Trump's 'Economic Nationalist' Agenda." Politico. Retrieved from https://www.politico.com/story/2016/11/ steve-bannon-trump-hollywood-reporter-interview-231624

O'Keefe, Daniel, 1983. Stolen Lightning: The Social Theory of Magic. New York: Vintage Books.

Panitch, Leo and Sam Gindin. 2012. The Making of Global Capitalism: The Political Economy of American Empire. Brooklyn, NY: Verso Books.

Piketty, Thomas. 2014. Capital in the Twenty-First Century. Cambridge, MA: Belknap Press of Harvard University Press.

Pirro, Jeanine. 2018. Liars, Leakers, and Liberals: The Case Against the Anti-Trump Conspiracy. New York, NY: Hachette Book Group.

Shapiro, Ben. 2019. The Right Side of History: How Reason and Moral Purpose Made the West Great. New York, NY: Broadside Books.

Silva, Sonia. 2013. "Reification and Fetishism: Processes of Transformation.” Theory, Culture, \& Society, 30(1): 79-98.

Smith, David. 1988. "Authorities, Deities, and Commodities: Classical Sociology and the Problem of Domination." Ph.D. dissertation, University of Wisconsin-Madison, Madison, WI.

Smith, David. 2006. "Authority Fetishism and the Manichean Vision: Stigma, Stereotyping, and Charisma as Keys to Pseudo-Orientation in an Estranged Society." Pp. 91-114 in The Evolution of Alienation: Trauma, Promise, and the Millenium. Edited by L. Langman and D. Kalekin-Fishman. United States of America: Rowman \& Littlefield Publishers, Inc.

Strauss, William and Neil Howe. 1997. The Fourth Turning: An American Prophecy. New York, NY: Three Rivers Press.

Styers, Randall. 2004. Making Magic: Religion, Magic, and Science in the Modern World. Oxford University Press.

Thompson, Michael. 2016. The Domestication of Critical Theory. United States of America: Rowman \& Littlefield International, Ltd.

Varoufakis, Yanis. 2011. The Global Minotaur: America, The True Origins of the Financial Crisis and the Future of the World Economy. New York, NY: Zed Books

Weber, Max. 1978. Economy and Society: An Outline of Interpretive Sociology. University of California Press.

Worrell, Mark. 2018. The Sociogony: Social Facts and the Ontology of Objects, Things, and Monsters. Brill. 